\title{
Last Reported Free Visit
}

National Cancer Institute

\section{Source}

National Cancer Institute. Last Reported Free Visit. NCI Thesaurus. Code C159698.

An indication of the last visit during which an individual was noted to be without something. 